\title{
Hubungan Antara Tingkat Pengetahuan Dan Sikap Pengunjung Terhadap Kepuasan Tentang Klinik Wisata Di Water Blaster Semarang
}

\author{
Widiyaningsih ${ }^{1}$, Eni Kusyati ${ }^{2}$, Hilmi Aziz Yusma ${ }^{3}$ \\ 1. STIKes Karya Husada Semarang \\ 2. STIKes Karya Husada Semarang \\ 3. STIKes Karya Husada Semarang \\ E-mail:widiya@stikesyahoedsmg.ac.id
}

\begin{abstract}
Abstrak
Water Blaster merupakan wahana permainan air yang pertama kali berdiri di Semarang dan menjadi andalan rekreasi keluarga warga kota Semarang. Setiap tahunnya jumlah pengunjung yang berkunjung ke Water Blaster selalu mengalami peningkatan. Peningkatan jumlah wisatawan tersebut akan diikuti peningkatan resiko kesehatan dikarenakan aktifitas kepariwisataan merupakan aktifitas yang dapat menimbulkan resiko kecelakaan, sehingga dibutuhkan adanya fasilitas klinik wisata. Sehubungan dengan hal diatas maka telah tersedia fasilitas pelayanan kesehatan khusus menangani masalah kesehatan pada wisatawan di kawasan wisata yang dikenal dengan nama klinik wisata.Tujuan Penelitian untuk mengetahui hubungan antara tingkat pengetahuan dan sikap pengunjung terhadap kepuasan tentang klinik wisata di Water Blaster Semarang. Jenis penelitian ini adalah kuantitatif korelasi dengan pendekatan cross section.Pengambilan data dengan menggunakan kuesioner.Jumlah responden sebanyak 51orang dengan teknik Purposive sampling.Data yang diperoleh diolah secara statistic menggunakan rumus chi-square. Hasil penelitian didapatkan data pengunjung di Water Blaster Semarang yang mempunyai pengetahuan cukup sebanyak 25 responden (49,0\%). Pengunjung di Water Blaster Semarang yang mempunyai sikap positif sebanyak 29 responden (56,9\%). Pengunjung di Water Blaster Semarang yang mempunyai kepuasan puas sebanyak 28 responden (54,9\%). Simpulan Ada hubungan yang signifikan antara tingkat pengetahuan dan sikap pengunjung terhadap kepuasan tentang klinik wisata di Water Blaster Semarang.
\end{abstract}

\section{Kata Kunci: Kepuasan Pengunjung; Klinik Wisata; Pengetahuan; Sikap}

\section{The Correlation Betweenlevel Of Knowledge And Attitudes Tourist To The Satisfaction Of The Clinic Tour At Water Blaster Semarang}

\begin{abstract}
Water Blaster is a vehicle for water games first established in Semarang and become a mainstay of family recreation Semarang city residents. Every year the number of visitors who visited the Water Blaster always increase. The increase in the number of tourists will be followed by an increased risk of health because of tourism activities are activities that can pose a risk of accidents so that it takes their travel clinic facilities. In connection with the above it has provided health care facility specifically address the issue of health on tourists in the tourist area known as the travel clinic.Objective :To determine the relationship between the level of knowledge and attitudes of visitors to the satisfaction of travel clinics in Water Blaster Semarang. Methods: This study was a quantitative correlation study with cross section approach. The data obtained by using questionnaires. The total numbers of respondent were 51 people by using purposive sampling. The data obtained were processed statistically by applying the chi-square formula.Results: Visitors in Water Blaster Semarang Self Knowledge That had as many as 25 respondents (49,0\%). Visitors in Water Blaster Semarang who have a positive attitude as much as 29 respondents $(56,9 \%)$. Visitors in Water Blaster Semarang who have satisfied the satisfaction of as many as 28 respondents $(54,9 \%)$. Conclusion: There was a significant corelation between the level of knowledge and attitudes of visitors to the satisfaction of travel clinics in Water Blaster Semarang.
\end{abstract}

Jurnal SMART Keperawatan Sekolah Tinggi Ilmu Kesehatan (STIKes) Karya Husada Semarang www.stikesyahoedsmg.ac.id/ojs/index.php/sjkp(perawat) 
Keywords: Knowledge; Attitude; Satisfaction Tourist; Travel Clinic

\section{Pendahuluan}

Indonesia merupakan salah satu negara yang kaya akan sumber daya alam yang melimpah, keanekaragaman flora dan fauna, peninggalan sejarah, serta seni dan budaya yang unik dimana hal tersebut menyebabkan Indonesia menjadi salah satu negara tujuan wisatawan mancanegara maupun domestik dalam hal pariwisata. Indonesia kaya akan tempat wisata dari berbagai suku, budaya, keanekaragaman flora dan fauna serta peninggalan sejarah serta tempat-tempat menarik lainnya. Kota Semarang salah satu yang sering di kunjungi wisatawan. Beberapa tempat wisata di Kota Semarang yang sering dikunjungi salah satunya obyek wisata Water Blaster, yaitu merupakan wahana permainan air yang pertama kali berdiri di Semarang dan menjadi andalan rekreasi keluarga warga kota Semarang.

Setiap area Water Blaster Semarang dijaga dengan yang namanya lifeguard.Pihak manajemen menyediakan 20 lifeguard, diantaranya adalah $85 \%$ lifeguard pria dan $15 \%$ lifeguard wanita untuk mengantisipasi kecelakaan yang terjadi.Seorang lifeguard mengawasi keselamatan dan penyelamatan pengunjung di dalam wahana Water Blaster.Lifeguard adalah suatu profesi dalam bentuk keterampilan khusus sebagai pertolongan terhadap kecelakaan yang terjadi selama di air/kolam renang (Susanto, 2009).

Beberapa kasus menggambarkan kejadian tenggelam akibat pengawasan yang lemah, fasilitas yang kurang memadai, dan yang paling penting karena kegagalan dalam penanganan kasus darurat dalam kecelakaan di dalam air.Mengurangi kemungkinan tenggelam atau jenis cedera air lainnya merupakan tanggung jawab bersama antara pengunjung dan lifeguard.Lifeguard bukan satu-satunya faktor keselamatan dikolam renang. Faktor lain yang tidak kalah pentingnya antara lain, lengkapnya sarana prasarana pertolongan di air (kolam renang) (Susanto, 2009).

Peningkatan jumlah wisatawan tersebut akan diikuti peningkatan resiko kesehatan dikarenakan aktifitas kepariwisataan merupakan aktifitas yang dapat menimbulkan resiko kecelakaan, sehingga dibutuhkan adanya fasilitas klinik wisata. Wisatawan yang mengunjungi destinasi wisata biasanya kerapkali melupakan bahwa selalu ada resiko perjalanan selama berwisata terutama dalam hal kesehatan.Berwisata baik secara langsung atau tidak langsung dapat menyebabkan berbagai resiko kesehatan tergantung dari keadaan fisik wisatawan maupun 
tipe perjalanannya seperti contohnya wisatawan mungkin terpapar secara tiba-tiba dengan perubahan ketinggian, kelembaban, suhu, dan mikroba dimana hal tersebut dapat menyebabkan masalah kesehatan. Sehubungan dengan hal diatas maka telah tersedia fasilitas pelayanan kesehatan khusus menangani masalah kesehatan pada wisatawan di kawasan wisata yang dikenal dengan nama klinik wisata (Mardh, 2002).

Menurut Undang-Undang (UU) Kepariwisataan No. 10/ 2009 tentang Kepariwisataan dikatakan "wisatawan adalah orang yang melakukan wisata". Definisi wisatawan ini juga ditetapkan berdasarkan rekomendasi International Union of Office Travel Organization (IUOTO) dan World Tourism Organization (WTO).Wisatawan adalah seseorang atau sekelompok orang yang melakukan perjalanan ke sebuah atau beberapa negara di luar tempat tinggal biasanya atau keluar dari lingkungan tempat tinggalnya untuk periode kurang dari 12 bulan dan memiliki tujuan untuk melakukan berbagai aktivitas wisata (Ismayanti, 2011). Di sisi lain kewajiban pengusaha atau pengelola pariwisata salah satunya adalah memberikan kenyamanan, keramahan, perlindungan keamanan, dan keselamatan wisatawan serta memberikan perlindungan asuransi pada usaha pariwisata dengan kegiatan yang berisiko tinggi (Pasal 26 huruf d dan e UU Kepariwisataan).

Travel Clinic memberikan pelayanan kesehatan di area wisata diberikan di negara-negara maju untuk memenuhi kebutuhan warga mereka yang akan bepergian ke negara-negara berkembang. Sejauh ini negara-negara berkembang hanya dianggap sebagai daerah tujuan wisata yang mempunyai risiko kesehatan tertentu, bahkan dalam buku panduannya, World Health Organization hanya menyebutkan bahwa konsultasi pra-travel diperlukan oleh travellers yang bermaksud mengunjungi negara berkembang (Pakasi, 2006). Klinik wisata merupakan suatu fasilitas kesehatan dimana sifat pelayanan yang diberikan meliputi konsultasi pra-perjalanan, selama berwisata, setelah berwisata, serta upaya vaksinasi dan edukasi akan resiko terpapar agen infeksi dimana sebenarnya dapat dicegah sesuai dengan prinsip ilmu Travel Medicine (Mardh, 2002).

\section{Tinjauan Teoritis}

Kepuasan menurut Kamus Bahasa Indonesia adalah puas; merasa senang; perihal (hal yang bersifat puas, kesenangan, kelegaan dan sebagainya).Kepuasan dapat diartikan sebagai perasaan 
puas, rasa senang dan kelegaan seseorang dikarenakan mengkonsumsi suatu produk atau jasa untuk mendapatkan pelayanan yang nyaman dari suatu jasa.Kepuasan adalah perasaan senang atau kecewa yang muncul setelah membandingkan antara persepsi terhadap kinerja ataupun hasil suatu produk atau jasa serta harapan-harapan (Kotler, 2007). Menurut Irawan (2003), seorang pelanggan yang puas yaitu pelanggan yang merasa mendapatkan value (nilai) dari pemasok, produsen atau penyedia jasa, value ini berasal dari produk, pelayanan, sistem atau sesuatu yang bersifat emosi. Pelanggan yang puas yaitu pelanggan yang akan berbagi kepuasan dengan produsen atau penyedia jasa, bahkan pelanggan yang puas akan berbagi pengalaman terhadap pelanggan lain, sehingga akan menjadi referensi bagi perusahaan/penyedia jasa yang bersangkutan.Menurut Kotler (2004) mengidentifikasi empat metode untuk mengukur kepuasan yaitu sistem keluhan dan saran, ghost shopping, lost costumer analysis,dan survey kepuasan pelanggan.

Pengetahuan adalah hasil dari tahu, dan hasil tersebut akan diperoleh setelah orang melakukan penginderaan terhadap suatu objek tertentu. Penginderaan terjadi melalui panca indera manusia, yakni indera penglihatan, penciuman rasa, dan raba.Sebagian besar pengetahuan manusia diperoleh dari mata dan telinga (Notoatmodjo, 2007).Sedangkan menurut Taufik (2007), pengetahuan merupakan penginderaan manusia, atau hasil tahu seseorang terhadap objek melalui indera yang dimilikinya (mata, hidung, telinga, dan lain sebagainya).Menurut Notoatmodjo (2007) pengetahuan atau kognitif merupakan domain yang sangat penting untuk terbentuknya tindakan seseorang. Dari pengalaman dan penelitian ternyata perilaku yang didasari oleh pengetahuan akan lebih langgeng daripada perilaku yang tidak didasari oleh pengetahuan. Faktorfaktor yang mempengaruhi pengetahuan yaitu faktor internal dan faktor eksternal, faktor internal antara lain pendidikan, usia, pengalaman, sedangkan faktor eksternal yaitu media/informasi, social budaya dan ekonomi, dan lingkungan. Cara pengukuran pengetahuan dilakukan dengan wawancara atau angket (kuesioner) yang menanyakan tentang materi yang ingin diukur dari subjek penelitian atau responden.Kedalaman pengetahuan yang ingin diketahui atau diukur dapat disesuaikan dengan tingkatan-tingkatan di atas.(Nursalam, 2008).

Sikap merupakan reaksi atau respon seseorang yang masih tertutup dari seseorang terhadap suatu stimulus atau obyek.Manifestasi sikap itu tidak dapat langsung dilihat tetapi hanya dapat menafsirkan terlebih dahulu dari perilaku yang tertutup, sikap secara nyata menunjukan konotasi adanya kesesuaian reaksi terhadap stimulus tertentu dalam kehidupan sehari-hari merupakan 
reaksi yang bersifat emosional terhadap stimulus sosial (Notoatmodjo, 2007). Massen, Krech dan dkk berpendapat bahwa sikap itu merupakan suatu sistem dari tiga komponen yang saling berhubungan, yaitu kognisi (pengenalan), feeling (perasaan), danaction tendency (kecenderungan untuk bertindak) (Yusuf, 2006). Sedangkan Sarlito Wirawan Sarwono mengemukakan, bahwa sikap adalah kesiapan seseorang bertindak terhadap hal-hal tertentu (Azwar, 2007).Menurut Notoatmodjo (2007) Sikap terdiri dari berbagai tingkatan yakni menerima, merespon, menghargai, dan bertanggung jawab. Sedangkan faktor-faktor yang mempengaruhi sikap yaitu pengalaman pribadi, pengaruh orang lain, pengaruh kebudayaan, dan media massa.

\section{Metode Penelitian}

Penelitian ini merupakan penelitian observational dengan metode cross sectional yaitu mencari hubungan antara variable yang ada.Populasi dalam penelitian ini diambil data dari bulan Februari sampai Juni 2016. Rata-rata populasi perbulan berjumlah 9.141 pengunjung, sedangkan rata-rata populasi perhari berjumlah 305 pengunjung. Pada penelitian ini penulis menggunakan rata rata populasi perhari.Sampel terdiri dari 51 responden, yaitu pengunjung di Water Blaster Semarang dan telah memenuhi kriteria penelitian yang telah ditentukan.Variabel yang diukur pada penelitian ini adalah tingkat pengetahuan pengunjung, sikap pengunjung dan kepuasan pengunjung.Teknik pengambilan data menggunakan kuesioner.Analisis analitik dilakukan dengan uji chi square. Semua uji analitik menggunakan $\mathrm{p}=0,05$.

\section{Hasil Penelitian}

Tabel 1. Distribusi Frekuensi Tingkat Pengetahuan Pengunjung Tentang Klinik Wisata Di Water Blaster Semarang

\begin{tabular}{lcc}
\hline Pengetahuan & Frekuensi & Persentase(\%) \\
\hline Baik & 14 & 27.5 \\
Cukup & 25 & 49.0 \\
Kurang & 12 & 23.5 \\
\hline Total & 51 & 100.0 \\
\hline
\end{tabular}

Berdasarkan hasil analisis tabel 1. diatas, diperoleh 14 dari 51 responden $(27,5 \%)$ mempunyai pengetahuan baik, 25 responden $(49,0 \%)$ mempunyai pengetahuan cukup, dan 12 responden $(23,5 \%)$, mempunyai pengetahuan kurang. 
Tabel 2. Distribusi Frekuensi Sikap Pengunjung Tentang Klinik Wisata Di Water Blaster Semarang

\begin{tabular}{lcc}
\hline Sikap & Frekuensi & Persentase(\%) \\
\hline Positif & 29 & 56.9 \\
Negatif & 22 & 43.1 \\
\hline Total & 51 & 100.0 \\
\hline
\end{tabular}

Berdasarkan hasil analisis tabel 2. diatas, diperoleh 29 dari 51 responden $(56,9 \%)$ mempunyai sikap positif, dan 22 responden $(43,1 \%)$ mempunyai sikap negatif.

Tabel 3.Distribusi Frekuensi Kepuasan Pengunjung Tentang Klinik Wisata Di Water Blaster Semarang

\begin{tabular}{lcc}
\hline Kepuasan & Frekuensi & Persentase (\%) \\
\hline Puas & 28 & 54.9 \\
Tidak Puas & 23 & 45.1 \\
\hline Total & 51 & 100.0 \\
\hline
\end{tabular}

Berdasarkan hasil analisis tabel 3. diatas, diperoleh 28 dari 51 responden $(54,9 \%)$ mempunyai kepuasan puas, dan 23 responden $(45,1 \%)$ mempunyai kepuasan tidak puas.

Tabel 4. Tabel Silang Antara Tingkat Pengetahuan Pengunjung Terhadap Kepuasan Tentang Klinik Wisata Di Water Blaster Semarang

\begin{tabular}{|c|c|c|c|c|c|c|c|c|}
\hline \multirow{3}{*}{ Pengetahuan } & \multicolumn{4}{|c|}{ Kepuasan } & & & \multirow{3}{*}{$\mathbf{X}^{2}$} & \multirow{3}{*}{ p_value } \\
\hline & \multicolumn{2}{|c|}{ Puas } & \multicolumn{2}{|c|}{$\begin{array}{l}\text { Tidak } \\
\text { Puas }\end{array}$} & \multicolumn{2}{|c|}{ Jumlah } & & \\
\hline & $\mathrm{N}$ & $\%$ & $\mathrm{~N}$ & $\%$ & $\mathrm{~N}$ & $\%$ & & \\
\hline Baik & 11 & 78,6 & 3 & 21,4 & 14 & 100 & 10.516 & 0,005 \\
\hline Cukup & 15 & 60 & 10 & 40 & 25 & 100 & & \\
\hline Kurang & 2 & 16,6 & 10 & 83,4 & 12 & 100 & & \\
\hline Jumlah & 28 & 54,9 & 23 & 45,1 & 51 & 100 & & \\
\hline
\end{tabular}

Berdasarkan tabel 4. maka dapat diketahui bahwa dari jumlah 14 responden (100\%) yang mempunyai pengetahuan baik dengan kepuasan puas sebanyak 11 responden $(78,6 \%)$ dan yang mempunyai pengetahuan baik dengan kepuasan tidak puas sebanyak 3 responden $(21,4 \%)$, dari 
jumlah 25 responden (100\%) yang mempunyai pengetahuan cukup dengan kepuasan puas sebanyak 15 responden (60\%) dan yang mempunyai pengetahuan cukup dengan kepuasan tidak puas sebanyak 10 responden (40\%), sedangkan 12 responden (100\%) yang mempunyai pengetahuan kurang dengan kepuasan puas yaitu sebanyak 2 responden $(16,6 \%)$ dan yang mempunyai pengetahuan kurang dengan kepuasan tidak puas sebanyak 10 responden $(83,4 \%)$.

\section{Tabel 5. Tabel Silang Antara Hubungan Sikap Pengunjung Terhadap Kepuasan Tentang Klinik Wisata Di Water Blaster Semarang}

\begin{tabular}{|c|c|c|c|c|c|c|c|c|}
\hline \multirow{3}{*}{ Sikap } & \multicolumn{4}{|c|}{ Kepuasan } & \multirow{2}{*}{\multicolumn{2}{|c|}{ Jumlah }} & \multirow{3}{*}{$\mathbf{X}^{2}$} & \multirow{3}{*}{ p_value } \\
\hline & \multicolumn{2}{|c|}{ Puas } & \multicolumn{2}{|c|}{ Tidak puas } & & & & \\
\hline & $\mathrm{N}$ & $\%$ & $\mathrm{~N}$ & $\%$ & $\mathrm{~N}$ & $\%$ & & \\
\hline Positif & 21 & 72,4 & 8 & 27,6 & 29 & 100 & 6.768 & 0,009 \\
\hline Negatif & 7 & 31,9 & 15 & 68,1 & 22 & 100 & & \\
\hline Jumlah & 28 & 54,9 & 23 & 45,1 & 51 & 100 & & \\
\hline
\end{tabular}

Berdasarkan tabel silang di atas maka dapat diketahui bahwa dari jumlah 29 responden (100\%) yang mempunyai sikap positif dengan kepuasan puas sebanyak 21 responden $(72,4 \%)$ dan yang mempunyai sikap positif dengan kepuasan tidak puas sebanyak 8 responden $(27,6 \%)$, sedangkan dari jumlah 22 responden $(100 \%)$ yang mempunyai sikap negatif dengan kepuasan puas yaitu sebanyak 7 responden $(31,9 \%)$ dan yang mempunyai sikap negatif dengan kepuasan tidak puas sebanyak 15 responden $(68,1 \%)$.

\section{Pembahasan}

Berdasarkan hasil analisis tabel 1 diperoleh 14 dari 51 responden (27,5\%) mempunyai pengetahuan baik, 25 responden $(49,0 \%)$ mempunyai pengetahuan cukup, dan 12 responden $(23,5 \%)$, mempunyai pengetahuan kurang. Hasil penelitian ini menunjukkan bahwa pengunjung yang mempunyai tingkat pengetahuan kurang tentang klinik wisata di Water Blaster Semarang sebesar 12 responden $(23,5 \%)$. Hal tersebut terjadi karena beberapa responden belum mempunyai pengetahuan yang luas seputar klinik wisata sebagai suatu fasilitas kesehatan, Padahal klinik wisata merupakan suatu fasilitas kesehatan dimana yang sifat pelayanan diberikan di area wisata, guna menunjang keamanan keamanan di wilayah sekitar area tempat 
wisata bila ada korban cidera atau tenggelam di area wisata khususnya di Waster Blaster Semarang (Mardh, 2002).

Berdasarkan hasil analisis tabel 2. diperoleh 29 dari 51 responden $(56,9 \%)$ mempunyai sikap positif, dan 22 responden $(43,1 \%)$ mempunyai sikap negatif. Sikap merupakan kesiapan untuk bereaksi terhadap objek di lingkungan tertentu sebagai salah satu penghayatan terhadap objek (Notoatmodjo, 2007). Hasil penelitian ini menunjukkan bahwa pengunjung yang mempunyai sikap negatif tentang klinik wisata sebanyak 22 responden $(43,1 \%)$. Proses pembentukan sikap dapat terjadi karena adanya rangsangan, seperti pengetahuan pengunjung tentang klinik wisata untuk memberi respon, dapat berupa sikap positif atau negatif, akhirnya dapat diwujudkan dalam perilaku atau tidak. Hal ini terjadi karena kurangnya pengetahuan yang sangat berpengaruh terhadap sikap yang negatif, serta dapat dilihat kurangnya pengetahuan pengunjung dalam menyikapi klinik wisata sebagai suatu tempat mengatasi korban cidera atau tengelam diarea wisata, serta dapat membantu untuk meminimalisir terjadi kecelakaan, sehingga pengunjung merasa nyaman ketika berkunjung dan bermain di area wisata Waster Blaster Semarang.

Azwar (2011) menyimpulkan bahwa faktor-faktor yang mempengaruhi sikap adalah pengalaman pribadi. Middlebrook (dalam Azwar,2011) mengatakan bahwa tidak adanya pengalaman yang dimiliki oleh seseorang dengan suatu objek psikologis, cenderung akan membentuk sikap negative terhadap objek tersebutAzwar (2011).Wisatawan mancanegara selalu menganggap bahwa di setiap tempat wisata ada klinik wisata, Itu berarti mereka sudah memiliki pengalaman, berbeda dengan wisatawan domestik masih banyak yang belum mengenal klinik wisata.

Berdasarkan hasil analisis tabel 3.diperoleh 28 dari 51 responden $(54,9 \%)$ mempunyai kepuasan puas, dan 23 responden $(45,1 \%)$ mempunyai kepuasan tidak puas. Seorang pelanggan yang puas yaitu pelanggan yang merasa mendapatkan value (nilai) dari pemasok, produsen atau penyedia jasa, value ini berasal dari produk, pelayanan, sistem atau sesuatu yang bersifat emosi. Pelanggan yang puas yaitu pelanggan yang akan berbagi kepuasan dengan produsen atau penyedia jasa, bahkan pelanggan yang puas akan berbagi pengalaman terhadap pelanggan lain, sehingga akan menjadi referensi bagi perusahaan/penyedia jasa yang bersangkutan (Irawan, 2003). Hasil penelitian ini menunjukkan bahwa kepuasan tidak puas pengunjung tentang klinik wisata sebanyak 23 responden $(45,1 \%)$. 
Dalam hal ini karena pelayanan dan fasilitas kesehatan yang diberikan pihak pengelola Waster Blaster Semarang kepada pengunjung masih kurang, sehingga memungkinkan pengunjung masih belum memahami bahwa di Waster Blaster Semarang mempunyai klinik wisata sebagai tempat untuk berobat atau konsultasi seputar keluhan penyakit yang diderita pada saat berwisata. Faktor-faktor yang mempengaruhi kepuasan salah satu indikator bahwa pelayanan sudah baik adalah terbentuknya kepuasan yang dirasakan oleh pelanggan sebagai pengguna jasa pelayanan

Berdasarkan tabel 4. maka dapat diketahui bahwa dari jumlah 14 responden (100\%) yang mempunyai pengetahuan baik dengan kepuasan puas sebanyak 11 responden $(78,6 \%)$ dan yang mempunyai pengetahuan baik dengan kepuasan tidak puas sebanyak 3 responden $(21,4 \%)$, dari jumlah 25 responden (100\%) yang mempunyai pengetahuan cukup dengan kepuasan puas sebanyak 15 responden (60\%) dan yang mempunyai pengetahuan cukup dengan kepuasan tidak puas sebanyak 10 responden (40\%), sedangkan 12 responden (100\%) yang mempunyai pengetahuan kurang dengan kepuasan puas yaitu sebanyak 2 responden (16,6\%) dan yang mempunyai pengetahuan kurang dengan kepuasan tidak puas sebanyak 10 responden $(83,4 \%)$.

Berdasarkan hasil penelitian, peneliti melakukan analisa data dengan menggunakan perhitungan secara statistik melalui uji Chi square dengan tingkat kesalahan (5\%) dengan kebebasan $(\mathrm{df})=1$ Setelah data diolah ternyata terdapat 0 sel $(0 \%)$ yang mempunyai nilai harapan $<5$, sehingga dianalisis menggunakan Chi Square dengan tingkat probabilitas $\alpha: 0,05$. Dari hasil olah data didapatkan nilai Chi Square sebesar 10.516 dengan p value sebesar 0,005 $<0,05$, maka hipotesa (Ho) ditolak dan Hipotesa $(\mathrm{Ha})$ diterima, berarti ada hubungan antara tingkat pengetahuan pengunjung terhadap kepuasan tentang klinik wisata di Water Blaster Semarang.

Hasil penelitian menunjukkan bahwa masih ada responden yang mempunyai pengetahuan baik tetapi memiliki kepuasan tidak puas yaitu 3 responden $(21,4 \%)$, salah satunyadisebabkan oleh faktor eksternal seperti pernyataan kuesioner yaitu terjatuh dari ketinggian pada saat bermain adalah salah satu faktor penyebab akibat kurang memahami informasi seputar klinik wisata sebanyak 29 responden 56,8\%. Pernyataan diatas menunjukkan bahwa media/informasi memberikan pengaruh terhadap pengetahuan seseorang dan berdampak terhadap ketidakpuasan terhadap pengunjung. 
Menurut Notoatmodjo (2007), pengaruh seseorang dipengaruhi oleh beberapa faktor eksternal dan internal, adapun faktor eksternal antara lain: umur, pendidikan, pekerjaan dan paparan informasi yang diperoleh dari masing-masing individu. Mengingat umur adalah salah satu faktor yang dapat mempengaruhi pengetahuan seseorang, maka semakin cukup umur, tingkat kematangan seseorang akan lebih tinggi pada saat berfikir dan bekerja sebagai akibat dari pengalaman dan kematangan jiwa.

Selain umur, faktor penyebab yang menyebabkan pengetahuan cukup tetapi memiliki kepuasan tidak puas sebanyak 10 responden (40\%). Hal ini disebabkan oleh pendidikan yang rendah, karena pendidikan merupakan salah satu institusi yang mana sesorang di didik, dilatih serta dibekali ilmu yang relevan dengan kehidupan, akibat dari pendidikan yang rendah akan menyebabkan seseorang mengalami keterbelakangan wawasan, cara berfikir dan tidak memiliki keterampilan dalam pekerjaan. Ini dibuktikan dengan data demografi yang sebagian besar berpendidikan terakhir SD yaitu 22 responden $(43,1 \%)$, itu berarti mereka masih dalam proses belajar untuk mencapai pendidikan yang tinggi. Dengan modal tersebut, mereka akan dengan mudah menerima informasi sehingga pengetahuan akan bertambah.

Faktor internal yang menyebabkan pengetahuan seseorang kurang tetapi memiliki kepuasan puas yaitu 2 responden $(16,6 \%)$ antara lain kesadaran pribadi kurang, kesadaran dalam mempengaruhi pengetahuan sangat penting mengingat seseorang bila tidak menyadari untuk memiliki keingginan tumbuh dan maju orang tersebut akan mengalami keterlambatan dalam hal pengetahuan baik secara wawasan, pemikiran dan kemajuan dalam bidang lainya. Faktor penyebab lainnya yaitu Intelgensi (IQ), kurangnya pengetahuan dalam hal intelegensi akan menyebabkan daya pikir dan daya tangkap yang dimiliki seseorang kurang, sehingga menghambat dalam proses berpikir dan bertindak (Notoatmodjo, 2007).

Hal tersebut berdampak terhadap kepuasan dari responden, menurut Hardiansyah dalam Hidayah (2015) pelayanan berkualitas memuaskan bila pelayanan tersebut dapat memenuhi kebutuhan dan harapan masyarakat.

Hasil penelitian ini sejalan dengan penelitian yang dilakukan Prabawa dan Trapika (2014), yaitu terdapat hubungan Antara Sikap Dan Tingkat Pengetahuan Seputar Klinik Wisata Pada Wisatawan Domestik Maupun Mancanegara Terhadap Pemanfaatan Klinik Wisata Di Kawasan Wisata Pantai Kuta, Bali. 
Berdasarkan tabel 5.maka dapat diketahui bahwa dari jumlah 29 responden (100\%) yang mempunyai sikap positif dengan kepuasan puas sebanyak 21 responden $(72,4 \%)$ dan yang mempunyai sikap positif dengan kepuasan tidak puas sebanyak 8 responden (27,6\%), sedangkan dari jumlah 22 responden (100\%) yang mempunyai sikap negatif dengan kepuasan puas yaitu sebanyak 7 responden $(31,9 \%)$ dan yang mempunyai sikap negatif dengan kepuasan tidak puas sebanyak 15 responden $(68,1 \%)$.

Berdasarkan hasil penelitian, peneliti melakukan analisa data dengan menggunakan perhitungan secara statistik melalui uji Chi square dengan derajat kepercayaan (95\%) dengan kebebasan $(\mathrm{df})=1$ Setelah data diolah ternyata terdapat 0 sel $(0 \%)$ yang mempunyai nilai harapan $<5$, sehingga dianalisis menggunakan Chi Square dengan tingkat probabilitas $\alpha$ : 0,05. Dari hasil olah datadidapatkan nilaiChi Square sebesar 6.768 dengan p value sebesar $=0,009<$ 0,05, maka hipotesa (Ho) ditolak dan Hipotesa (Ha) diterima berarti ada hubungan antara sikap pengunjung terhadap kepuasan tentang klinik wisata di Water Blaster Semarang.

Hasil penelitian menunjukkan bahwa masih ada responden yang mempunyai sikap positif tetapi memiliki kepuasan tidak puas sebanyak 8 responden $(27,6 \%)$. Hal tersebut ditandai dengan pernyataan kuesioner saya kurang setuju dengan fasilitas klinik wisata karena fasilitas kurang memadai dengan peralatan yang sedikit sebanyak 33 responden $64,7 \%$. Hal ini disebabkan oleh beberapa faktor yang mempengaruhi sikap yaitu pengalaman pribadi, pengaruh orang lain yang dianggap penting, pengaruh kebudayaan, media massa. Hal ini sesuai dengan penelitian yang dilakukan oleh peneliti dimana sikap pengunjung terhadap kepuasan tentang klinik wisata dipengaruhi beberapa faktor salah satunya pendidikan, dimana sebagian besar pendidikan terakhir pengunjung adalah SD yaitu 22 responden $(43,1 \%)$, sehingga memiliki pemahaman yang kurang baik tentang klinik wisata yang dapat mempengaruhi responden dalam bersikap (Azwar, 2011).

Hasil penelitian ini memberikan gambaran bahwa sikap pengunjung akan berdampak terhadap kepuasan tentang klinik wisata di Water Blaster Semarang. Kenyataan tersebut sesuai dengan pendapat Hurriyati (2005), Kotler (2003), Lupiyoadi (2011) yang menyatakan bahwa sikap dalam memberikan pelayanan merupakan salah satu faktor yang mempengaruhi kepuasan konsumen.

Selain pendidikan, yang menyebabkan sikap negatif dengan kepuasan puas sebanyak 7 responden $(31,9 \%)$ yaitu media massa, media massa juga berpengaruh terhadap sikap 
seseorang. Berbagai bentuk media massa seperti televisi, radio, surat kabar, majalah dan lainlain mempunyai pengaruh yang besar dalam pembentukan opini dan kepercayaan individu. Media massa memberikan pesan-pesan yang sugestif yang mengarahkan opini seseorang. Adanya informasi baru mengenai sesuatu hal memberikan landasan kognitif baru bagi terbentuknya sikap terhadap hal tersebut.

Roger (1974) dalam Notoatmodjo (2007) memiliki pendapat yaitu sikap dan praktek yang tidak didasari oleh pengetahuan yang adekuat tidak akan bertahan lama pada kehidupan seseorang, sedangkan pengetahuan yang adekuat jika tidak diimbangi oleh sikap dan praktek yang berkesinambungan tidak akan mempunyai makna yang berarti bagi kehidupan. Berdasarkan hasil analisa dapat diartikan bahwa pengetahuan dan sikap merupakan penunjang dalam melakukan perilaku, yang dalam hal ini sikap positif berdampak terhadap kepuasan pengunjung di Water Blaster Semarang.

Penelitian ini sejalan dengan hasil penelitian yang dilakukan oleh Martiani dan Pramono (2012), yaitu terdapat hubungan tingkat pengetahuan dan sikap wisatawan terhadap pemanfaatan klinik wisata di Candi Borobudur.

\section{Kesimpulan}

Hasil penelitian menunjukkan ada hubungan antara tingkat pengetahuan pengunjung terhadap kepuasan tentang klinik wisata di Water Blaster Semarang dan ada hubungan antara sikap pengunjung terhadap kepuasan tentang klinik wisata di Water Blaster Semarang.

\section{Saran}

Bagi pengelola Water Blaster perlu melakukan sosialisasi lebih luas mengenai fungsi dan keberadaan klinik wisata dari pengelola Water Blaster Semarang kepada pengunjung guna untuk meningkatkan kualitas pelayanan tentang klinik wisata..

\section{Daftar Pustaka}

Ismayanti. (2011). Pengantar Pariwisata. Jakarta: Grasindo.

Kotler, P. T., \& Keller, K. L. (2004). Manajemen Pemasaran. Edisi 13.Jakarta : Erlangga.

Lupiyoadi, R., \& Hamdani, A. (2001). Manajemen Pemasaran Jasa.Jakarta: Salemba Empat.2001

Jurnal SMART Keperawatan Sekolah Tinggi Ilmu Kesehatan (STIKes) Karya Husada Semarang 
Martiani N., \&Pramono. (2012). Hubungan Tingkat Pengetahuan dan Sikap Wisatawan Terhadap Pemanfaatan Klinik Wisata: Studi Kasus Kawasan Wisata Candi Borobudur. Eprints Undip: 56-63.

Mardh PA. (2002). What is travel medicine? Content, current position, tools and tasks. J Travel Med: 34-47.

Pakasi, L.S.. (2006). Pelayanan Kedokteran Wisata: Suatu Peluang. Cermin Dunia Kedokteran: 152 .

Prabawa, P. Y., \& Trapika, G. M. S. C. (2014). Hubungan Antara Sikap Dan Tingkat Pengetahuan Seputar Klinik Wisata Pada Wisatawan Domestik Maupun Mancanegara Terhadap Pemanfaatan Klinik Wisata Di Kawasan Wisata Pantai Kuta, Bali.

Taufik, M. (2007) Prinsip-Prinsip Promosi Kesehatan Dalam Bidang Keperawatan.Jakarta: Infomedika.

Susanto, E. (2009). Pelatihan Dasar-Dasar Keamanan Air Bagi Pengawas Kolam Renang (Lifeguard) se-DIY.Inotek. 2009. 13(2): 121-134.

_. (2009). Undang-Undang Kepariwisataan No. 10 2009.UNDANG-UNDANG REPUBLIK INDONESIA. 